\title{
The Application of Experiential Teaching Method in College English Teaching
}

\author{
Jie Chen \\ School of Foreign Languages, Northwestern Polytechnical University, Xi’an, Shaanxi, 710129
}

Keywords: Application, Experiential Teaching Method, College English Teaching

\begin{abstract}
Experiential teaching method has been widely regarded as an effective English teaching method in English teaching in our country and applied to practical teaching. This paper, combined with the application of experiential English teaching in college English teaching, explores the specific contents of this teaching method and some problems that should be paid attention to in practical application.
\end{abstract}

\section{Introduction}

The experiential learning method is an effective learning method in foreign language education in recent years. On the basis of the theory and practice of experiential learning, the English educators put forward the experiential foreign language in practice Teaching methods, and with its unique advantages of access to the global foreign language education institutions of all ages, in the actual teaching played an important role, showing good results. In view of the overall situation of English education in China, it is very necessary for us to carry out experiential teaching method in all levels of school English education to enhance the overall effectiveness of English education.

\section{The Experience Teaching Methods}

The basic meaning of experiential teaching method is that in the course of regular classroom teaching, in order to achieve the specific teaching purpose, teaching demand as the starting point, import, create and design and teaching content and consistent with the scene and atmosphere, can effectively help students understand Learning content, and better will be applied to the actual content of the exchange process, to promote the psychological and harmonious functioning of students all-round development. This method of teaching is to strengthen the teachers and students through the emotional experience to create interactive forms of interaction, which have a positive effect. Experiential pedagogy is rooted in experiential learning theory. Experiential learning not only emphasizes students with brain to think, but also requires students to see with eyes, hands to do, mouth said, in person to experience, intentions to experience. Because the acquisition of cognition, concept, etc. is derived through the experience, so if there is no interaction between the subject and the object can not get the results of the experience.

\section{The Theoretical Basis of Experiential Teaching Model}

The Constructivism Theory. Constructivism is an important branch of cognitive learning theory. It is the result of the deepening study of the cognitive law of human learning process. It is the further development of behaviorism. The main points of its teaching theory are: ${ }^{1}$ learners are not passive acceptance of information and the learning process is the learners according to their needs, interests, love the use of the original cognitive structure (knowledge and experience) on the external information to take the initiative to choose and the process of processing.

Knowledge is the unity of each learner through learning. Students who are not passive stimulators of external stimuli are active constructors of cognitive subject and intellectual meaning. The ultimate result of this active and independent construction is the gradual reduction of the 
control from the teacher, the student's self-control learning ability. "Interaction is an important means of building meaning. $1 / 4$ teachers in the teaching process plays an intermediary role, is the student to achieve the goal of learning "one of the tools", so the role of teachers can not be ignored. Teachers not only impart knowledge, but also play the initiative of students to stimulate the potential of learning and intrinsic motivation to help students automatically build knowledge. In short, the constructivist teaching theory is very profound and comprehensive interpretation of the "College English teaching requirements".

Student-Center Theory. "Student-centered" is the teaching principle proposed by the communicative language teaching method. It embodies the teaching thought of the student's subject theory, that is, in the teaching, the student is the subject and the teacher is the leading. Nunan argues that "learner-centered curricula rely on the joint efforts of teachers and learners, learners should be actively involved in determining the content of teaching and how to teach." Taking into account the factors of students in foreign language teaching, social factors and second language the student-centered classroom activity is not to let the students' free activities, students to complete the learning process, but teachers for students to create a learning environment, according to the content of the design of different tasks, to guide students to complete learning tasks.

Nunan's Experiential Model Teaching. Compared with the traditional teacher-centered teaching model, the experiential teaching model has the following main characteristics: ${ }^{1}$ teaching methods and teaching content in accordance with the actual needs of learners designed; ${ }^{\circ}$ teacher to teach language knowledge, learners actively participate in the use of Language, in the use of secondary schools; »learners learn how to use language creatively; $1 / 4$ learners learn to write a fine illustrations of textbooks, but also with self-learning materials, tapes, CD-ROM, and the use of modern means; $1 / 2$ learners in the classroom learning how to apply these strategies to post-class self-study; $3 / 4$ learners form a pair or group, learn how to work with people, and how to express their opinions and feelings; Learners themselves assess the progress of their studies and discover their strengths and weaknesses.

This experiential teaching model is the practical reflection of constructivist learning theory, student center theory and autonomous learning theory. It emphasizes learners, with the help of teachers and learning partners, constructs language meaning autonomously, learns language in the process of using language, and emphasizes learner's ability to cultivate autonomous learning ability. Its classroom activities reflect the learner's dominant position and the real needs of communication.

\section{The Necessity of Using Experiential Teaching Method in the College English Teaching}

Experiential learning emphasizes the initial experience and experience accumulation in the student learning process. It emphasizes that students transform their learning into their own knowledge and strengthen and master their own learning process. Experiential teaching method is based on the development of English teaching theory, in view of the advantages and effectiveness of experiential learning, learning from its learning model and built a new teaching method. Unlike traditional teaching method which is centered on the teacher, this method is a student-centered approach in which students learn to develop their own autonomy and reflect and practice to acquire knowledge and develop attitudes. It not only focused on practical learning, but also focused on the experience and through the summary and reflection to gain experience and the accumulation of interest.

At present, there are many problems in college English education, such as single and inefficient teaching mode, lack of interaction in the classroom, monotonous boring, insufficient self-learning ability of students, poor teaching effect and so on. These are not conducive to the mastery of students' knowledge, and even alienated their learning motivated need to reform. Therefore, the current college English teaching in our country should change the status quo of "teaching and learning", actively introduce experiential teaching method, enter fresh blood for college English education, so as to improve the teaching effect and make students really learn. 


\section{The Experiential Teaching Methods in College English Education}

According to the relevant principles of experiential learning methods, experiential teaching methods get continuous innovation and development in the practical application of $\mathrm{t}$, the formation of a set of distinctive and effective method of the system. Specifically include:

Create the Situation. The situation here refers to emotional situations and learning situations. The creation of emotional situations focuses on correcting students' motivation to learn, motivating their interest and cultivating a good learning attitude. Creating a learning situation focuses on building a diverse learning style. The way to create a situation is its diverse, mainly picture reproduction, physical presentation, language description, audio and video tutorials and so on. For example, the use of audio and video tutorials to create emotional situations, in the study of this chapter of the Olympic Games, the first use of multimedia and Olympic-related film and television information, so that students intuitively feel the knowledge, and thus stimulate the interest of students learning. In the creation of learning situations, you can use a variety of learning methods, such as the form of groups such as lectures, theater performances, debates and other activities.

Innovative Teaching Model. The rapid development of multimedia technology and network technology provides the conditions for us to break the traditional single teaching model based on teacher teaching. At present, we should support the information technology, so that English teaching is no longer rigidly adhere to the time, place restrictions, towards the diversification, individualization, autonomy direction, in English teaching practicality, knowledge and fun combination The principle to ensure that students in the English classroom on the dominant position. Specifically, the innovation of the teaching model should be fully covered and run through the following four stages: pre-class material preparation, classroom experience, classroom knowledge induction, classroom and post-class language use. Our actual teaching results show that through these four complete stages of experiential teaching, students' English proficiency has improved dramatically. In addition, outside the classroom, schools should take a variety of ways to create conditions for students to learn English independently. At this point, the current college English education in China generally open college students' autonomous learning center is to provide students with a wealth of English independent learning resources efficient platform.

Interactive Learning. One of the biggest shortcomings of traditional teacher-led English education is the lack of interaction between teachers and students. In the experiential English teaching, interactive learning is the central part of teaching. Students use the experiential English learning system, play the advantages of multimedia technology, in the classroom to strengthen the interaction between teachers and students, making the classroom vibrant, and then stimulate students to learn interest, improve classroom efficiency and student learning effect. Taking our English experiential teaching as an example, our school has set up a series of courses: "University Experience English Series Course" and "University Experience English Listening, Listening and Speaking of Internet Tutorial". After one year of teaching practice, our school has basically built multimedia English autonomous learning model, students' interest in English and learning initiative improved significantly, teaching effect is remarkable.

Knowledge Construction. Knowledge building focuses on enabling students to experience success and transform indirect experience into direct experience. The main methods are the following: (1) Students through the topic discussion, role-playing and other forms to show their own knowledge, and strengthen the learning effect. (2) Evaluation feedback. Feedback in the English teaching process has an important role in the timely and correct feedback can strengthen the students get the right knowledge, correct the error, make up for deficiencies, but also can strengthen and stimulate students to learn motivation. It is worth noting that the feedback process itself is a very interactive process, in this process to pay attention to the close interaction between teachers and students. (3) Teaching evaluation. The main form of teaching assessment is the examination, which mainly through the study of students' comprehensive English ability on the one hand to check the student's learning effect, on the other hand, to increase the learning experience, deepen the learning effect.

Experiential English Teaching Strategies. At present, the research on college English 
experiential teaching strategies is also quite significant. The author here mainly introduces three strategies, namely, asynchronous strategy, incentive strategy and practical strategy.

(1) Asynchronous strategy refers to the teacher in the teaching process, from the student learning differences from the status quo, to design the teaching objectives, content, methods and guidance evaluation.

(2) Incentive strategy emphasizes not to force learning, but to stimulate students' interest in learning, when students from knowledge recipients into knowledge constructors, the study of interest, confidence has been induced and maintained, learning effect also Correspondingly enhanced.

(3) Practical strategies focus on students' practical application of knowledge. It requires the design and development of a series of practical activities within and outside the classroom (such as oral contest, role play and business English simulation negotiations), the students' English knowledge into English skills. This method has a great effect on improving the students' ability of language application and the lack of English skills in college English education.

\section{Problems that Should Be Paid Attention to in the Process of College English Experiential Teaching}

At present, some universities in China have noticed the importance of English experiential teaching and adopted this teaching method in practical teaching. However, due to some shortcomings in the current situation of English education in China and the characteristics of this method and some Lack of, we in the actual teaching process should also pay attention to the following questions.

Compared with the traditional teaching mode, the role of teachers and students in experiential English teaching should be: the role of teachers is the guide and collaborator of students' new learning in the process of autonomous learning. The role of students is the active participant of teaching activities and active constructors of knowledge. Scientific and rational relationship between teachers and students is an important guarantee to carry out experiential teaching. Therefore, teachers should pay attention to this. In the actual English teaching of our university, teachers should pay attention to this and strengthen and improve the experience through the construction of reasonable teacher-student relationship in practical teaching.

\section{Conclusion}

Although experiential teaching has many advantages, but it still has some shortcomings, such as requiring teachers and students spend a lot of time to achieve the experience of the process, the overall progress of the teaching will have a certain impact. At the same time, it is also a challenge to teachers' teaching ability and ability to control. In addition, in the teaching process, teachers need to pay attention to avoid a single teaching method, the combination of different teaching methods to achieve "teach the law, but no law."

\section{References}

[1] Mu Zhengfang.Experimental teaching method in college English teaching teaching [J]. China Science and Education Innovation Guide, 2009, (02): 54

[2] Zhang Tongle, Li Xiaolu, Hu Rong. Exploring the educational principles of college English experiential teaching [J].Journal of Anhui Science and Technology University, 2008, (06): 35-38

[3] Hong Lifeng, Liu Menglan, Wang Qian. College English teaching experience learning and teaching strategies [J] Journal of Taiyuan Urban Vocational College, 2009, (03): 85-86 (in Chinese with English abstract)

[4] Li Liling; Yu Hanrui.Application of experiential teaching method in college English teaching[J]. 
Education and Occupation .2009 (03): 144-146

[5] Chi Juan. College English experiential teaching [J]. Journal of Southwest Ethnic Teachers' College, 2009, (03): 38-41 